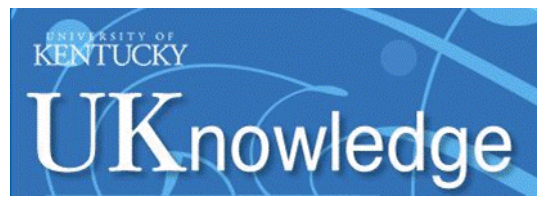

University of Kentucky

UKnowledge

Biosystems and Agricultural Engineering

Faculty Publications

Biosystems and Agricultural Engineering

2016

\title{
Effects of Chemical Amendments to Swine Manure on Runoff Quality
}

\author{
Elizabeth L. Bullock \\ University of Kentucky \\ Dwayne R. Edwards \\ University of Kentucky, dwayne.edwards@uky.edu \\ Phillip A. Moore Jr. \\ USDA Agricultural Research Service \\ Richard S. Gates \\ University of Illinois at Urbana-Champaign
}

Follow this and additional works at: https://uknowledge.uky.edu/bae_facpub

Part of the Agriculture Commons, Bioresource and Agricultural Engineering Commons, Environmental Sciences Commons, and the Soil Science Commons

Right click to open a feedback form in a new tab to let us know how this document benefits you.

\section{Repository Citation}

Bullock, Elizabeth L.; Edwards, Dwayne R.; Moore, Phillip A. Jr.; and Gates, Richard S., "Effects of Chemical Amendments to Swine Manure on Runoff Quality" (2016). Biosystems and Agricultural Engineering Faculty Publications. 50.

https://uknowledge.uky.edu/bae_facpub/50

This Article is brought to you for free and open access by the Biosystems and Agricultural Engineering at UKnowledge. It has been accepted for inclusion in Biosystems and Agricultural Engineering Faculty Publications by an authorized administrator of UKnowledge. For more information, please contact UKnowledge@lsv.uky.edu. 


\section{Effects of Chemical Amendments to Swine Manure on Runoff Quality \\ Digital Object Identifier (DOI) \\ https://doi.org/10.13031/trans.59.11636 \\ Notes/Citation Information \\ Published in Transactions of the ASABE, v. 59, issue 6, p. 1651-1660. \\ (c) 2016 American Society of Agricultural and Biological Engineers \\ The copyright holder has granted the permission for posting the article here.}




\title{
EFFECTS OF CHEMICAL AMENDMENTS TO SWINE MANURE ON RUNOFF QUALITY
}

\author{
E. L. Bullock, D. R. Edwards, P. A. Moore, Jr., R. S. Gates
}

\begin{abstract}
Land-applied swine manure can be an environmental concern when runoff losses of manure constituents occur. The use of chemical amendments to mitigate these losses has been investigated for poultry litter, but materials such as swine manure have received less attention in this context, particularly at the plot scale or larger. The objective of this experiment was to evaluate the impacts of aluminum sulfate (alum; $\left.\mathrm{Al}_{2}\left(\mathrm{SO}_{4}\right)_{3}\right)$, aluminum chloride $\left(\mathrm{AlCl}_{3}\right)$, and ferric chloride ( $\mathrm{FeCl}_{3}$ ) addition on runoff of selected constituents of land-applied swine manure. Manure was collected from feeder pigs fed a standard diet. Alum and $\mathrm{FeCl}_{3}$ were added at a stoichiometric ratio of 1.1:1 [Al:total P (TP)], and $\mathrm{AlCl}_{3}$ was added at a ratio of 1.3:1 [Al:TP]. The amended manure was incubated for six days prior to land application to fescue (Festuca arundinacea Schreber) plots. Simulated rainfall (100 $\mathrm{mm} \mathrm{h}^{-1}$ for $0.5 \mathrm{~h}$ of runoff) was applied to the plots on the day of application and followed by two additional simulated rainfall events at $7 d$ intervals. Runoff samples were collected and analyzed for dissolved reactive phosphorus (DP), TP, ammonia nitrogen $\left(\mathrm{NH}_{3}-\mathrm{N}\right)$, nitrate nitrogen $\left(\mathrm{NO}_{3}-\mathrm{N}\right)$, total Kjeldahl nitrogen $(T K N)$, total suspended solids (TSS), fecal coliform (FC), and $17 \beta$-estradiol. Runoff concentrations of all constituents except $\mathrm{NO}_{3}-\mathrm{N}$ were highest for the first simulated rainfall event, approaching background levels thereafter. Relative to untreated manure, all chemical amendments were effective in reducing first-event DP, TP, and TKN concentrations. Both $\mathrm{AlCl}_{3}$ and $\mathrm{FeCl}_{3}$ reduced first-event $\mathrm{NH}_{3}-\mathrm{N}$ concentrations, and $\mathrm{FeCl}_{3}$ addition led to $\mathrm{FC}$ concentrations indistinguishable from the control (no manure) plots. The results indicate that these amendments have potential for promoting both environmental and agronomic benefits, implying that studies involving practicality and long-term considerations should be undertaken.
\end{abstract}

Keywords. Chemical amendments, Runoff, Swine manure.

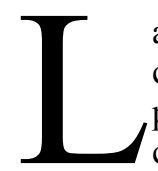
arge-scale swine production facilities have become increasingly common in the U.S. over the past four decades. While pork production increased by just over $75 \%$ from 1977 to 2012 , the number of hog operations decreased by $90 \%$ over the same period (National Pork Board, 2014). Beneficial impacts of land-applied swine manure have been well-documented; Choudhary et al. (1996) reviewed multiple studies reporting that swine manure performed as well as, or better than, inorganic fertilizers in terms of pasture and crop yields. However, the increasing spatial concentration of swine, and thus manure, production often raises environmental concerns regarding land application of manure, including runoff transport of nutrients, bacteria, and hormones to downstream waters.

Submitted for review in November 2015 as manuscript number NRES 11636; approved for publication by the Natural Resources \& Environmental Systems Community of ASABE in August 2016.

Mention of company or trade names is for description only and does not imply endorsement by the USDA. The USDA is an equal opportunity provider and employer.

The authors are Elizabeth L. Bullock, Former Graduate Assistant, and Dwayne R. Edwards, Professor, Department of Biosystems and Agricultural Engineering, University of Kentucky, Lexington, Kentucky; Philip A. Moore, Jr., Soil Scientist, USDA-ARS Poultry Production and Products Safety Research, Fayetteville, Arkansas; Richard S. Gates, ASABE Fellow, Professor, Department of Agricultural and Biological Engineering, University of Illinois, Urbana, Illinois. Corresponding author: Dwayne Edwards, 106 C.E. Barnhart Building, University of Kentucky, Lexington, KY 40546-0276; phone: 859-257-5657; e-mail dwayne.edwards@uky.edu.
Nutrient losses from land application sites are of interest primarily for their ability to promote increased productivity in downstream waters. Both phosphorus (P) and nitrogen (N) have the potential to increase growth of algae and aquatic vegetation and thus accelerate the natural process of eutrophication in water bodies. It is generally accepted that eutrophication rates for most inland waters are limited by $\mathrm{P}$ inputs (Schindler, 1977). Sharpley et al. (1992) and Sonzogni et al. (1982) discussed bioavailability of $\mathrm{P}$ and noted that dissolved $\mathrm{P}$ is the most directly bioavailable form of $\mathrm{P}$, while particulate $\mathrm{P}$ is more of a reservoir for subsequent release to aquatic organisms. Runoff losses of $\mathrm{N}$ can accelerate eutrophication in water bodies that already have sufficiently high P (i.e., N-limited). If present in sufficiently high concentrations under conditions of elevated $\mathrm{pH}$, ammonia $\mathrm{N}$ $\left(\mathrm{NH}_{3}-\mathrm{N}\right)$ can be directly harmful to fish (e.g., Diricx et al., 2013). As discussed by Burton (2007), runoff-borne solids are associated with insoluble forms of $\mathrm{N}$ and $\mathrm{P}$ as well as with additional oxygen-demanding materials. Bacteria and other microorganisms in surface waters are a concern for disease transmission, mainly through activities such as fishing and swimming.

While the environmental implications of nutrients, solids, and bacteria in land-applied animal manure are relatively well-known and have been studied for decades, more recent studies have seen increasing emphasis on the presence and effects of endocrine disruptors. The steroidal hormone $17 \beta$ estradiol (17BE) has been detected in poultry litter (Shore et al., 1993; Nichols et al., 1997) and swine manure (Burnison 
et al., 2003). Additionally, Schiffer et al. (2001) identified trenbolone acetate and melengestrol acetate in cattle manure. Concerns regarding endocrine disruptors in animal manures are related to their potential adverse effects on exposed vertebrate and invertebrate species, as discussed by Sharpe and Shakkebaek (1993), Tijani et al. (2013), and others.

A considerable body of literature has established that, under unfavorable conditions (e.g., high rainfall occurring shortly after application), land application of swine manure can promote elevated runoff concentrations of manure constituents. Burns et al. (1985) applied swine lagoon effluent to Coastal bermudagrass [Cynodon dactylon (Linnaeus) Persoon] on Wagram loamy sand and Norfolk loamy sand plots at three rates $\left(335,670\right.$, and $1340 \mathrm{~kg} \mathrm{~N} \mathrm{ha}^{-1}$ year $\left.^{-1}\right)$ from 1973 to 1979. At the medium and high application rates, large proportions of $\mathrm{N}$ ( $43 \%$ for the medium and $66 \%$ for the high) were unrecovered in the forage and therefore potentially available for surface and/or subsurface transport. In the same study, King et al. (1985) found that the majority of the P was recovered in the soil, with a minimum of $65 \%$ recovery.

Burns et al. (1987) applied four treatments (commercial fertilizer as control, swine manure applied as slurry, and two swine manure lagoon effluents based on different $\mathrm{N}$ application rates of 600 and $1200 \mathrm{~kg} \mathrm{~N} \mathrm{ha}^{-1}$ ) to a temperate forage mixture on a Cecil sandy clay loam and collected data from 1975 to 1978 . Their data showed that the swine lagoon effluent treatments led to the largest quantities of $\mathrm{N}(64 \%$ and $36 \%$ for the low and high application rates, respectively) and $\mathrm{P}$ (39\% and $23 \%$, respectively) unrecovered in the forage and available to enter runoff and groundwater. In a similar study, Westerman et al. (1987) concluded that swine lagoon effluent applied at $1200 \mathrm{~kg} \mathrm{~N}^{-1}$ led to $47 \%$ unrecovered $\mathrm{N}$, which could contribute to surface and groundwater pollution.

Edwards and Daniel (1993) studied the impacts of swine manure applied to fescue (Festuca arundinacea Schreber) plots. A $3 \times 2$ factorial design with three replications was used for the experiment, with the variables being manure application rate and rainfall intensity. The manure was applied at rates of 0,217 , and $435 \mathrm{~kg} \mathrm{~N}^{-1}$ to $1.5 \mathrm{~m} \times 6.0 \mathrm{~m}$ plots on a Captina silt loam. Simulated rainfall was then applied at high $\left(100 \mathrm{~mm} \mathrm{~h}^{-1}\right)$ and low $\left(50 \mathrm{~mm} \mathrm{~h}^{-1}\right)$ intensities. The results showed that runoff concentrations of analyzed parameters (total Kjeldahl $\mathrm{N}(\mathrm{TKN}), \mathrm{NH}_{3}-\mathrm{N}$, nitrate $\mathrm{N}\left(\mathrm{NO}_{3}\right.$ $\mathrm{N}$ ), total $\mathrm{P}$ (TP), dissolved reactive $\mathrm{P}$ (DP), chemical oxygen demand (COD), and total suspended solids (TSS)) were highest when simulated rainfall occurred soon after application. Dissolved reactive P accounted for at least $80 \%$ of the TP in all treatments, and $60 \%$ of the TKN consisted of $\mathrm{NH}_{3-}$ $\mathrm{N}$. Subsequent simulated rainfall after the first event produced runoff having substantially lower concentrations of all analyzed parameters.

Several methods have been used to reduce runoff concentrations of swine manure constituents. Chaubey et al. (1994) used vegetative filter strips (VFS) to reduce sediment and nutrient losses from plots treated with liquid swine manure. The plots were established in fescue on a Captina silt loam soil with dimensions of $1.5 \mathrm{~m} \times 24 \mathrm{~m}$ and a uniform slope of $3 \%$. Swine manure was applied to the upper $3 \mathrm{~m}$ of each of three plots. Simulated rainfall was applied five days after manure application at an intensity of $50 \mathrm{~mm} \mathrm{~h}^{-1}$, and VFS effectiveness was assessed at lengths of $0,3,6,9,15$, and $21 \mathrm{~m}$. Vegetative filter strips as short as $3 \mathrm{~m}$ removed significant quantities of TKN $(65 \%), \mathrm{NH}_{3}-\mathrm{N}(71 \%)$, DP $(65 \%)$, and TP $(67 \%)$ but did not significantly reduce mass transport of $\mathrm{NO}_{3}-\mathrm{N}$ or $\mathrm{FC}$ from the incoming runoff.

The use of chemical amendments such as $\mathrm{Al}_{2}\left(\mathrm{SO}_{4}\right)_{3}$ (alum) and $\mathrm{FeCl}_{3}$ represents another possible technique for reducing runoff losses of nutrients in land-applied swine manure. Chemical amendments have long been used in water treatment applications due to their ability to inactivate $\mathrm{P}$ (Malecki-Brown et al., 2009). However, reports of their use in manure treatment are relatively recent. Moore and Miller (1994) mixed Al, Ca, and $\mathrm{Fe}$ amendments with poultry litter, added deionized water to achieve $20 \%$ water content by volume, and incubated the mixture in the dark at $25^{\circ} \mathrm{C}$ for one week. These authors found that all three amendments were successful in reducing soluble P levels in poultry litter. In a follow-up study, Shreve et al. (1995) amended poultry litter with alum and ferrous sulfate and applied the amended litter to fescue plots. Relative to non-amended poultry litter, the chemical amendments reduced runoff $P$ concentrations during the first simulated rainfall event by up to $87 \%$ for alum and up to $77 \%$ for ferrous sulfate. In a similar study, Busheé et al. (1998) amended horse stall bedding (straw, manure, and urine) and treated municipal sludge with alum, after which the mixtures were applied to fescue plots. Alum addition reduced runoff DP concentrations to background (no bedding or sludge) levels for the horse stall bedding. For the plots receiving sludge, alum addition reduced runoff DP by $78 \%$ relative to non-amended sludge.

More recent studies reported by European scientists have expanded the available information on the potential benefits of chemical amendment addition to animal manures. O'Flynn et al. (2012) added alum, $\mathrm{FeCl}_{3}$, and poly-aluminum chloride (PAC) at rates of 0.88:1 [Al:TP], 0.89:1 $[\mathrm{Al}: \mathrm{Fe}]$, and $0.72: 1$ [Al:TP] to pig manure slurry prior to application to grassed sod in runoff boxes. While all amendments reduced runoff (three events from simulated rainfall) concentrations of $\mathrm{P}$ and suspended solids (SS) relative to untreated slurry, the researchers reported that the performance of PAC was superior to that of alum and $\mathrm{FeCl}_{3}$, achieving concentration reductions in excess of $70 \%$. In a related study, O'Flynn et al. (2013) evaluated the effects of the previously mentioned amendments in combination with varying time intervals $(12,24$, and $48 \mathrm{~h})$ between pig manure slurry application and simulated rainfall. Each amendment again reduced runoff concentrations of $\mathrm{P}$ and SS relative to untreated slurry, but there was no significant difference among amendments' performance. The authors concluded that, for runoff $\mathrm{P}$ and SS, chemical amendments might be more beneficial than attempting to time manure application to achieve a specifically legislated application-to-rainfall interval, but that economic and other considerations argued for a relatively targeted approach in practical application. In a later study using the same basic experimental apparatus, Murnane et al. (2015) added PAC with and without zeolite to dairy and pig manure slurry. Results from three simulated rainfall 
events corroborated earlier findings of the amendments' effects on $\mathrm{P}$ and SS concentrations in runoff and further demonstrated a beneficial effect on runoff $\mathrm{N}$, with additional runoff quality benefits upon addition of zeolite. Brennan et al. (2012) reported results from a small $(0.9 \mathrm{~m} \times 0.4 \mathrm{~m})$ field plot study that were consistent with the previously cited laboratory-scale studies. When added to dairy manure slurry, PAC and alum reduced TP and DP concentrations by $82 \%$ to $98 \%$ for runoff from the first of three simulated rainfall events. Amendment performance with regard to $\mathrm{N}$ was variable, with alum increasing (by $81 \%$ ) and PAC decreasing (by $82 \%$ ) runoff $\mathrm{NH}_{3}-\mathrm{N}$ concentrations in runoff from the first simulated rainfall event.

The studies discussed above on chemical amendments to animal manures indicate that there is consistent evidence of a potential environmental benefit in using chemical amendments to mitigate runoff losses of land-applied animal manure constituents. The objective of this study was to conduct a field plot-scale assessment of the potential runoff quality benefits of treating swine manure with chemical amendments prior to land application.

\section{MATERIALS AND METHODS}

The manure for the experiment was collected at the Cold Stream Research Facility of the University of Kentucky Agricultural Experiment Station from approximately 60 tenweek-old feeder pigs that were confined to feeding crates. Collection trays were placed under the crates to capture all wastes, and water was diverted from the automated watering devices during collection. Collection occurred over a twoday period, after which the manure was added to a large container for mixing and distribution.

The mixed manure was equally (45 L) distributed among 12 cylindrical plastic containers to simulate pit storage and transported to the University of Kentucky campus. Nine of the 12 containers were treated with alum, $\mathrm{AlCl}_{3}$, or $\mathrm{FeCl}_{3}$ (three replications of each chemical amendment), while the remaining three containers received no amendment. The alum was added in the form of a $10 \%$ alum solution at $10 \%$ by volume (i.e., $4.5 \mathrm{~L}$ of $10 \%$ alum solution per alum-treated container), resulting in a stoichiometric rate of 1.1:1 [Al:TP]. The alum application rate was somewhat higher than that reported by O'Flynn et al. (2012) but was selected to be compatible with that used by earlier researchers (e.g., Shreve et al., 1995; Moore et al., 1998) who reported that alum application at similar rates decreased runoff transport of $\mathrm{P}$ and metals in surface-applied poultry litter. The rates of $\mathrm{FeCl}_{3}$ and $\mathrm{AlCl}_{3}$ were comparable at 1.1:1 [Al:TP] and 1.3:1 [Al:TP], respectively. It was anticipated that, due to the age of the feeder pigs, the amounts of $17 \mathrm{BE}$ in the manure would be insignificant and therefore undetectable when using the selected method of analysis for diluted runoff. Edwards and Daniel (1993) reported greater than 100-fold dilutions in runoff concentrations of some land-applied swine manure constituents relative concentrations in the manure itself. Therefore, 17BE was added to each container after the chemical amendments to achieve a target concentration of $0.04 \mathrm{mg} \mathrm{17BE} \mathrm{L} \mathrm{B}^{-1}$ (amounting to $0.545 \mathrm{~mL}$ of $17 \mathrm{BE}$ added to each container), the minimum manure concentration estimated as sufficient to produce detectable runoff $17 \mathrm{BE}$ concentrations when using typical analysis methods. The containers were manually stirred after all chemicals were added.

The containers were maintained in a temperature-controlled environment at an average temperature of $21^{\circ} \mathrm{C}$. A continuous airflow of $14.4 \mathrm{~m}^{3} \mathrm{~h}^{-1}$ was circulated through each container to simulate commercial farm pit ventilation as part of a related study involving gas emissions $\left(\mathrm{NH}_{3}, \mathrm{CO}_{2}\right.$, $\mathrm{CH}_{4}$, and $\mathrm{H}_{2} \mathrm{~S}$ ). Samples of the manure were collected from the containers at the conclusion of a six-day incubation period (the duration of which was selected to enable gas concentrations to stabilize) and analyzed for $\mathrm{pH}, \mathrm{DP}, \mathrm{TP}, \mathrm{NH}_{3}-$ $\mathrm{N}, \mathrm{NO}_{3}-\mathrm{N}, \mathrm{TKN}$, and 17BE using methods described later for runoff.

Fescue plots (mature stand, 100\% cover) at the Maine Chance Farm of the University of Kentucky Agriculture Experiment Station were used to assess runoff quality effects of the chemical amendments. The plots measure $2.44 \mathrm{~m} \times$ $6.10 \mathrm{~m}$ and have a $3 \%$ slope along the major axis. The soil at the site is Maury silt loam (fine, mixed, mesic Typic Paleudalf) and has been characterized by Perfect and Blevins (1997) and Barton and Karathanasis (2002). The plots are a maximum distance of $15 \mathrm{~m}$ from one another and, since their establishment in 1996, have received only minimal foot and equipment traffic for maintenance. Differences in runoff behavior should thus be attributable only to relatively smallscale variations in macropore and similar soil hydraulic characteristics. The runoff from each plot flows into a sloping aluminum gutter at the lowest edge of the plot, where it then flows through a short length of PVC pipe before falling freely into a sump and ultimately draining off-site. Runoff can be readily sampled with a $1 \mathrm{~L}$ container manually inserted into the free-flowing stream between the PVC pipe and sump bottom.

A total of 15 randomly selected plots (from a total of 30 available at the site) were used to assess the effects of the chemical amendments on runoff quality. Three days prior to soil sampling and manure application, each plot had been heavily irrigated to minimize soil moisture variability and subsequent effects on runoff variability. Soil samples (0 to $5 \mathrm{~cm}$ depth) were collected from each plot (two per plot at approximately one-third and two-thirds distance from the uppermost edge and along the longitudinal centerline) prior to manure application, and each of the 30 samples was individually analyzed for $\mathrm{P}$ (Mehlich, 1984) and $\mathrm{pH}$ (1:1 soil:water) by the University of Kentucky Division of Regulatory Services. Analyses indicated no systematic trends in either soil $\mathrm{P}\left(87.6 \pm 10.5 \mathrm{mg} \mathrm{kg}^{-1}\right)$ or $\mathrm{pH}(5.8 \pm 0.2)$. Twelve of the plots received the entire contents (applied to plot surfaces as uniformly as possible using modified, hand-held, commercial plant watering cans) of one randomly selected manure container, with a resulting volumetric application rate of $30.3 \mathrm{~m}^{3} \mathrm{ha}^{-1}$. The three remaining plots received no manure application and were used as controls.

Simulated rainfall was applied within $1 \mathrm{~h}$ of manure application at $102 \mathrm{~mm} \mathrm{~h}^{-1}$ until runoff had occurred from each plot for $0.5 \mathrm{~h}$. Given that an average duration of $0.28 \mathrm{~h}$ of rainfall was necessary to produce runoff, an average of 
$80 \mathrm{~mm}$ was applied to each plot over an average of $0.78 \mathrm{~h}$. This is an extremely intense and infrequent storm for central Kentucky, having a return period in excess of 200 years (Bonnin et al., 2006). The rationale for using this intensity was to ensure that runoff consistently occurred in a practical timeframe (thus enabling sample collection and fulfillment of the study objectives) rather than to simulate more commonplace rainfall events. Other experiences at the site (Busheé et al., 1998; Moss et al., 1999; Williams and Edwards, 2016) indicated that lower rainfall intensities could necessitate hours of simulated rainfall application prior to occurrence of runoff. The very short interval between manure application and simulated rainfall also drove experimental conditions in the direction of "worst-case scenario." Although surface application of manure is not recommended in the U.S. when runoff-producing rainfall is imminent (NRCS, 2012), there is great variation among the states in the legal nature and enforcement of such manure application practices (Patton and Seidl, 1999). A short interval between manure application and heavy rainfall is thus perhaps improvident and unfortunate, but not uniformly precluded by law or weather.

The simulated rainfall was applied using simulators (a total of five, each capable of simulating rainfall for a single plot) constructed by the University of Kentucky's Department of Biosystems and Agricultural Engineering. The simulators are based on the design and operation described by Humphry et al. (2002), who characterized its performance, but adapted as multi-nozzle versions to accommodate larger plot areas. The water source for the simulators was municipal water, samples of which were analyzed according to methods described later for the runoff samples.

Runoff was sampled from each plot at 2, 4, 8, 14, 22, and $30 \mathrm{~min}$ after the onset of continuous runoff. The times required to collect the samples (measured with a stopwatch) and sample volumes (collected over $60 \mathrm{~s}$ or to a maximum of $1 \mathrm{~L}$ ) were recorded for each of the six samples to determine plot runoff rates at the various sampling times (i.e., plot hydrographs). Knowledge of total plot runoff volumes (from numerical integration of the hydrographs) and sample volumes enabled the development of a single flow-weighted composite sample per plot, consisting of appropriate volumes drawn from the six individual samples, to represent runoff composition over the entirety of runoff. The composite samples (with a $50 \mathrm{~mL}$ portion filtered through $0.45 \mu \mathrm{m}$ pore diameter paper for $\mathrm{NO}_{3}-\mathrm{N}$ and DP analysis) were then stored at $4^{\circ} \mathrm{C}$ pending analysis.

Runoff samples were analyzed for DP, TP, $\mathrm{NH}_{3}-\mathrm{N}, \mathrm{NO}_{3}-$ $\mathrm{N}, \mathrm{TKN}, \mathrm{FC}, \mathrm{TSS}$, and 17BE. All analyses were conducted at the Department of Biosystems and Agricultural Engineering of the University of Kentucky, and standard methods of analysis (APHA, 2012) were used for each parameter except 17BE. Dissolved reactive $\mathrm{P}$ and $\mathrm{NO}_{3}-\mathrm{N}$ were analyzed by ion chromatography following filtration through $0.45 \mu \mathrm{m}$ pore diameter filter paper. Total $\mathrm{P}$ was analyzed by the ascorbic acid colorimetric method following sulfuric acid-nitrogen acid digestion. Ammonia $\mathrm{N}$ was determined from an ammonia-specific electrode. The macro-Kjeldahl method was used to analyze TKN. Total suspended solids were determined by filtration followed by drying at $103^{\circ} \mathrm{C}$ to $105^{\circ} \mathrm{C}$. Fecal coliform concentrations were measured using the membrane-filter technique. An enzyme-linked immunosorbent assay kit (ADI-900-008, Enzo Life Sciences, Farmingdale, N.Y.) was used according to vendor protocols to determine $17 \mathrm{BE}$ content.

Subsequent simulated rainfall applications occurred at seven and 14 days following the first application, with all experimental methods (simulated rainfall intensity, sample collection, sample analysis, etc.) identical to those previously described. The plots were not shielded from natural rainfall between the first and third simulated rainfall events, and a total of six natural rainfall events totaling $24 \mathrm{~mm}$ of rainfall occurred in this interval (but not on a simulated rainfall date).

Statistical analysis software (SigmaPlot, Systat Software, San Jose, Cal.) was used to perform two-way analysis of variance (ANOVA) with factors of manure treatment (control/no manure, unamended manure, alum-amended manure, $\mathrm{AlCl}_{3}$-amended manure, and $\mathrm{FeCl}_{3}$-amended manure), rainfall event (first, second, and third), and interaction. Tukey's test was used for means separation, and the significance level used in all statistical testing was $\mathrm{p}=0.05$.

\section{RESULTS AND DISCUSSION MANURE COMPOSITION}

As indicated in table 1, manure concentrations of DP (which was especially variable), $\mathrm{TP}, \mathrm{NH}_{3}-\mathrm{N}$, and $17 \mathrm{BE}$ were not significantly affected by addition of the chemical amendments. Significantly increased acidity was observed for each amendment, as expected, with the aluminum-based amendments producing the most acidic conditions. Only in the case of $\mathrm{FeCl}_{3}$ amendment were manure $\mathrm{NO}_{3}-\mathrm{N}$ concentrations significantly different from (higher than) unamended manure concentrations; however, manure $\mathrm{NO}_{3}-\mathrm{N}$ concentrations for $\mathrm{FeCl}_{3}$ amendment were not significantly different from the aluminum-based amendments. Similar to $\mathrm{NO}_{3}-\mathrm{N}$, significant differences in average TKN concentrations existed only between the highest (unamended) and lowest (alum amendment) values. Concentrations of FC just prior to manure application to the plots are unavailable. Average

Table 1. Manure composition. ${ }^{[\mathrm{a}]}$

\begin{tabular}{ccccc}
\hline \multirow{2}{*}{ Constituent } & Alum & $\mathrm{AlCl}_{3}$ & $\mathrm{FeCl}_{3}$ & Untreated \\
\cline { 2 - 5 } $\mathrm{pH}$ & 4.95 & 4.89 & 5.35 & 5.75 \\
& $\pm 0.05 \mathrm{c}$ & $\pm 0.15 \mathrm{c}$ & $\pm 0.05 \mathrm{~b}$ & $\pm 0.12 \mathrm{a}$ \\
\hline $\mathrm{DP}\left(\mathrm{mg} \mathrm{L}^{-1}\right)$ & 28.3 & 26.6 & 22.7 & 4.77 \\
& $\pm 39.5 \mathrm{~b}$ & $\pm 30.5 \mathrm{~b}$ & $\pm 30.9 \mathrm{a}$ & $\pm 2.13 \mathrm{~b}$ \\
\hline $\mathrm{TP}\left(\mathrm{mg} \mathrm{L}^{-1}\right)$ & 884 & 893 & 849 & 882 \\
& $\pm 26.5 \mathrm{a}$ & $\pm 80.4 \mathrm{a}$ & $\pm 25.5 \mathrm{a}$ & $\pm 97.0 \mathrm{a}$ \\
\hline $\mathrm{NH}_{3}-\mathrm{N}\left(\mathrm{mg} \mathrm{L}^{-1}\right)$ & 1681 & 1756 & 1719 & 1956 \\
& $\pm 201 \mathrm{a}$ & $\pm 87.8 \mathrm{a}$ & $\pm 120 \mathrm{a}$ & $\pm 176 \mathrm{a}$ \\
\hline $\mathrm{NO}_{3}-\mathrm{N}\left(\mathrm{mg} \mathrm{L}^{-1}\right)$ & 0.26 & 0.24 & 0.35 & 0.20 \\
& $\pm 0.04 \mathrm{ab}$ & $\pm 0.02 \mathrm{ab}$ & $\pm 0.03 \mathrm{a}$ & $\pm 0.01 \mathrm{~b}$ \\
\hline $\mathrm{TKN}\left(\mathrm{mg} \mathrm{L}^{-1}\right)$ & 3347 & 3743 & 3484 & 4153 \\
& $\pm 33.5 \mathrm{~b}$ & $\pm 487 \mathrm{ab}$ & $\pm 105 \mathrm{ab}$ & $\pm 208 \mathrm{a}$ \\
\hline $17 \mathrm{BE}\left(\mu \mathrm{g} \mathrm{L}^{-1}\right)$ & 3.49 & 3.23 & 1.93 & 2.56 \\
& $\pm 1.15 \mathrm{a}$ & $\pm 0.03 \mathrm{a}$ & $\pm 0.58 \mathrm{a}$ & $\pm 0.56 \mathrm{a}$ \\
\hline [a] & Values are means \pm standard deviations of three replications. Within- \\
row means followed by the same letter are not significantly different at &
\end{tabular}


Table 2. Application rates of manure constituents. ${ }^{\text {[a] }}$

\begin{tabular}{ccccc}
\hline & \multicolumn{4}{c}{ Manure Treatment } \\
\cline { 2 - 5 } Constituent & Alum & $\mathrm{AlCl}_{3}$ & $\mathrm{FeCl}_{3}$ & Untreated \\
\hline $\mathrm{DP}\left(\mathrm{kg} \mathrm{ha}^{-1}\right)$ & 0.87 & 0.82 & 0.70 & 0.15 \\
$\mathrm{TP}\left(\mathrm{kg} \mathrm{ha}^{-1}\right)$ & 27.4 & 27.7 & 26.3 & 27.3 \\
$\mathrm{NH}_{3}-\mathrm{N}\left(\mathrm{kg} \mathrm{ha}^{-1}\right)$ & 52.1 & 54.5 & 53.3 & 60.6 \\
$\mathrm{NO}_{3}-\mathrm{N}\left(\mathrm{kg} \mathrm{ha}^{-1}\right)$ & 0.01 & 0.01 & 0.01 & 0.01 \\
$\mathrm{TKN}\left(\mathrm{kg} \mathrm{ha}^{-1}\right)$ & 103.8 & 116.1 & 108.0 & 128.8 \\
$17 \mathrm{BE}\left(\mathrm{mg} \mathrm{ha}^{-1}\right)$ & 0.11 & 0.10 & 0.06 & 0.08 \\
\hline
\end{tabular}

Table 3. Hydrologic variables.

\begin{tabular}{cccccc}
\hline & \multicolumn{5}{c}{ Manure Treatment $^{[\mathrm{b}]}$} \\
\cline { 2 - 6 } Variable $^{[\mathrm{a}]}$ & Alum & $\mathrm{AlCl}_{3}$ & $\mathrm{FeCl}_{3}$ & Untreated & Control \\
\hline$R_{Q}(\mathrm{~mm})$ & 23.0 & 23.2 & 36.5 & 29.8 & 27.1 \\
& $\pm 10.6 \mathrm{~b}$ & $\pm 5.4 \mathrm{~b}$ & $\pm 11.7 \mathrm{a}$ & $\pm 10.4 \mathrm{ab}$ & $\pm 9.5 \mathrm{ab}$ \\
\hline$Q(\mathrm{~mm})$ & 28.6 & 22.0 & 16.3 & 19.0 & 21.0 \\
& $\pm 5.7 \mathrm{a}$ & $\pm 4.4 \mathrm{ab}$ & $\pm 7.5 \mathrm{~b}$ & $\pm 7.8 \mathrm{ab}$ & $\pm 6.1 \mathrm{ab}$ \\
\hline$Q: R(\%)$ & 39.8 & 30.0 & 19.6 & 24.8 & 27.6 \\
& $\pm 10.8 \mathrm{a}$ & $\pm 7.5 \mathrm{ab}$ & $\pm 11.0 \mathrm{~b}$ & $\pm 12.9 \mathrm{ab}$ & $\pm 9.7 \mathrm{ab}$ \\
\hline
\end{tabular}

[a] $R_{Q}$ is rainfall depth applied prior to the onset of runoff, $Q$ is runoff depth, and $Q: R$ is the ratio of runoff to total rainfall depth.

[b] Values are means \pm standard deviations of nine replications (three plots $\times$ three simulated rainfall events). Within-row means followed by the same letter are not significantly different at $\mathrm{p}=0.05$.

application rates resulting from the manure composition data in table 1 and the earlier-mentioned volumetric manure application rate are given in table 2 .

Table 3 provides statistics for the hydrologic variables measured and calculated for the experiment. These data are averaged across all three simulated rainfall events, since ANOVA indicated no significant differences among the first, second, or third events. However, differences in hydrologic variables due to manure treatments were identified. Although not different from the control or plots receiving unamended manure, the plots receiving $\mathrm{FeCl}_{3}$-amended manure required significantly more rainfall to produce runoff than the plots receiving manure with the aluminum-based amendments. Similarly, the plots receiving $\mathrm{FeCl}_{3}$-amended manure had significantly less runoff and a significantly lower runoff-to-rainfall ratio than the plots receiving alumamended manure. The plots receiving $\mathrm{FeCl}_{3}$-amended manure thus demonstrated an overall reduced runoff potential relative to those receiving alum-amended manure. No tentative hypothesis is presently proposed to explain the rainfallrunoff findings as related to chemical amendment; additional focused work would be necessary to further clarify this result.

\section{RUNOFF CONCENTRATIONS}

The composition of the water used as simulated rainfall is given in table 4 . Concentrations of all parameters were relatively low and therefore did not mask the effects of manure additions. Generally speaking, runoff concentrations of manure constituents were significantly affected by manure treatment, but only for the first runoff event. The exceptions were runoff $\mathrm{FC}$ concentrations (which did not vary significantly among rainfall events) and runoff $\mathrm{NO}_{3}-\mathrm{N}$ and $17 \mathrm{BE}$ concentrations, which were not significantly affected by manure treatment (i.e., all plots having manure applied were indistinguishable from plots receiving no manure of any kind) but varied significantly with simulated rainfall event.
Table 4. Characteristics of water used in simulated rainfall. ${ }^{[a]}$

\begin{tabular}{cc}
\hline Constituent & Mean \\
\hline $\mathrm{pH}$ & $7.7 \pm 0.08$ \\
$\mathrm{DP}\left(\mathrm{mg} \mathrm{L}^{-1}\right)$ & $0.27 \pm 0.03$ \\
$\mathrm{TP}\left(\mathrm{mg} \mathrm{L}^{-1}\right)$ & $0.35 \pm 0.04$ \\
$\mathrm{NH}_{3}-\mathrm{N}\left(\mathrm{mg} \mathrm{L}^{-1}\right)$ & $0.49 \pm 0.03$ \\
$\mathrm{NO}_{3}-\mathrm{N}\left(\mathrm{mg} \mathrm{L}^{-1}\right)$ & $0.31 \pm 0.15$ \\
$\mathrm{TKN}\left(\mathrm{mg} \mathrm{L}^{-1}\right)$ & $0.70 \pm 0.04$ \\
$\mathrm{TSS}\left(\mathrm{mg} \mathrm{L}^{-1}\right)$ & $0.47 \pm 0.57$ \\
$\mathrm{Fe}\left(\mathrm{mg} \mathrm{L}^{-1}\right)$ & $0.20 \pm 0.09$ \\
$\mathrm{Al}\left(\mathrm{mg} \mathrm{L}^{-1}\right)$ & $0.39 \pm 0.12$ \\
$\mathrm{FC}\left(\mathrm{mg} \mathrm{L}^{-1}\right)$ & $0.00 \pm 0.00$ \\
\hline
\end{tabular}

[a] Values are means \pm standard deviations of six samples.

Average (over all manure treatments) runoff $\mathrm{NO}_{3}-\mathrm{N}$ concentrations for the first $\left(0.42 \pm 0.10 \mathrm{mg} \mathrm{L}^{-1}\right)$ and second $(0.52$ $\left.\pm 0.15 \mathrm{mg} \mathrm{L}^{-1}\right)$ simulated rainfall events did not significantly differ from one another, but both were significantly different from those corresponding to the third $\left(0.27 \pm 0.09 \mathrm{mg} \mathrm{L}^{-1}\right)$ simulated rainfall event. Runoff concentrations of $17 \mathrm{BE}$ behaved similarly and was significantly greater for the first simulated rainfall event $\left(0.05 \pm 0.08 \mu \mathrm{g} \mathrm{L}^{-1}\right.$ averaged over all manure treatments) than for the second $\left(0.01 \pm 0.004 \mu \mathrm{g} \mathrm{L}^{-1}\right)$ and third $\left(0.01 \pm 0.005 \mu \mathrm{g} \mathrm{L}^{-1}\right)$ events. These findings are consistent with mineralization followed by plant uptake (for $\mathrm{NO}_{3}-\mathrm{N}$ ) and, similar to results of Lee and Liu (2002), degradation in the case of 17BE.

The remaining analysis parameters (DP, TP, $\mathrm{NH}_{3}-\mathrm{N}$, TKN, TSS, and FC) exhibited significant dependence on both manure treatment and simulated rainfall event. However, runoff concentration differences among manure treatments were significant only during the first simulated rainfall event. For the second and third simulated rainfall events, no significant differences attributable to manure treatment were present; in other words, concentrations of parameters in runoff from the plots receiving manure (regardless of the amendment, if any) were not significantly different from the control plots, which received no manure. This phenomenon of higher runoff concentrations of nutrients and solids during the first rainfall event than during subsequent events is consistent with findings reported by several scientists (e.g., McLeod and Hegg, 1984; Edwards and Daniel, 1994a; Nichols et al., 1997; Vadas et al., 2007; O’Flynn et al., 2012).

Each of the three chemical amendments investigated was highly effective in reducing runoff DP concentrations during the first simulated rainfall event. As shown in figure 1, runoff DP concentrations from the plots receiving chemically amended (whether alum, $\mathrm{AlCl}_{3}$, or $\mathrm{FeCl}_{3}$ ) manure were on average less than one-fifth of the DP concentrations measured from plots receiving unamended manure (significant at $\mathrm{p}=0.05$ ) and were statistically indistinguishable from background levels (i.e., not significantly different from the control plots, which received no manure) with no significant differences among chemical amendments. This result is in agreement with findings of O'Flynn et al. $(2012,2013)$ and is attributed to the amendments' precipitation of soluble DP to produce insoluble mineral forms, as reported, for example, by Moore et al. (1999). While first-event TP concentrations from all plots receiving manure were significantly greater than from the control plots, each of the chemical amendments was effective in significantly reducing runoff 


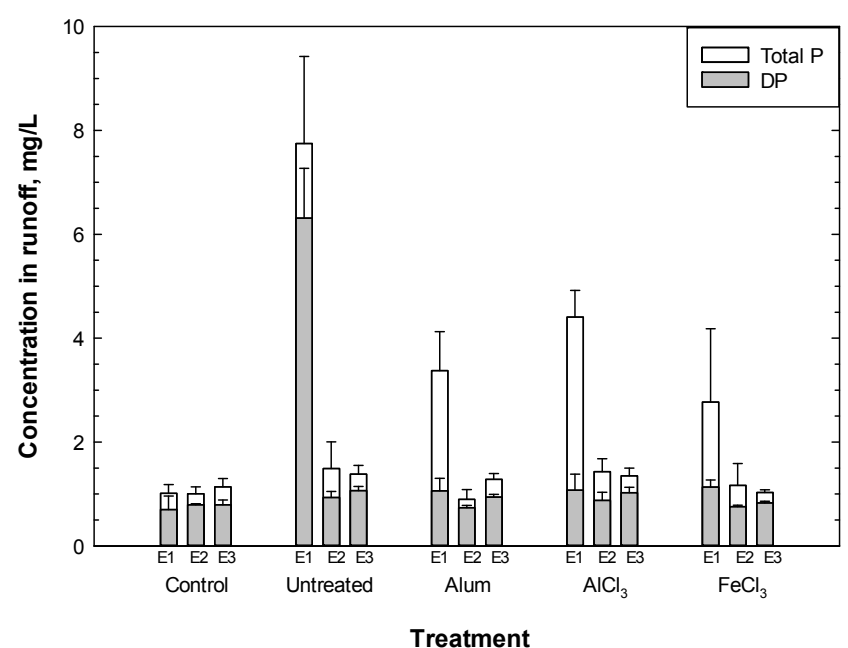

Figure 1. Flow-weighted mean (of three replications) runoff total $P$ and dissolved reactive $P$ (DP) concentrations for the first (E1), second (E2), and third (E3) simulated rainfall events. Error bars indicate one standard deviation.

TP concentrations (fig. 1) relative to unamended manure, and $\mathrm{FeCl}_{3}$ amendment resulted in runoff TP concentrations that were significantly less than from $\mathrm{AlCl}_{3}$ amendment. However, this result is seen to have occurred largely by virtue of the amendments' effects on DP rather than on other P forms (particulate and dissolved unreactive P). As shown in figure 2, first-event TSS concentrations from all plots receiving manure were significantly greater than from the control plots. Furthermore, none of the chemical amendments significantly reduced TSS concentrations relative to unamended manure, consistent with the earlier-discussed findings with respect to TP. This finding is consistent with results reported by O'Flynn et al. (2012), who found that, relative to untreated pig manure slurry, addition of alum or $\mathrm{FeCl}_{3}$ did not significantly reduce runoff concentrations of suspended sediment.

The effects of manure treatment on runoff $\mathrm{NH}_{3}-\mathrm{N}$ and TKN concentrations are shown in figure 3. First-event concentrations of $\mathrm{NH}_{3}-\mathrm{N}$ from all plots receiving manure were

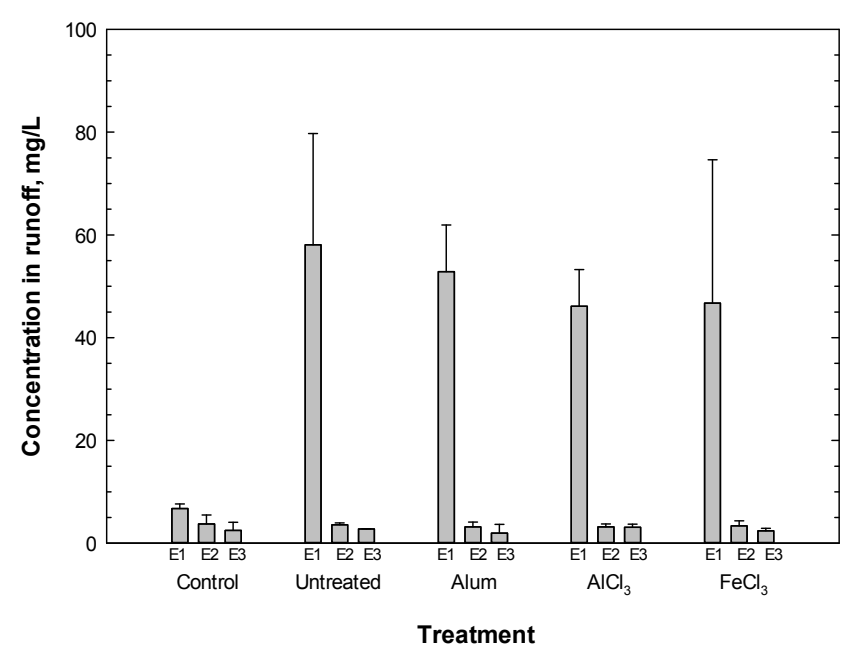

Figure 2. Flow-weighted mean (of three replications) runoff total suspended solids concentrations for the first (E1), second (E2), and third (E3) simulated rainfall events. Error bars indicate one standard deviation.

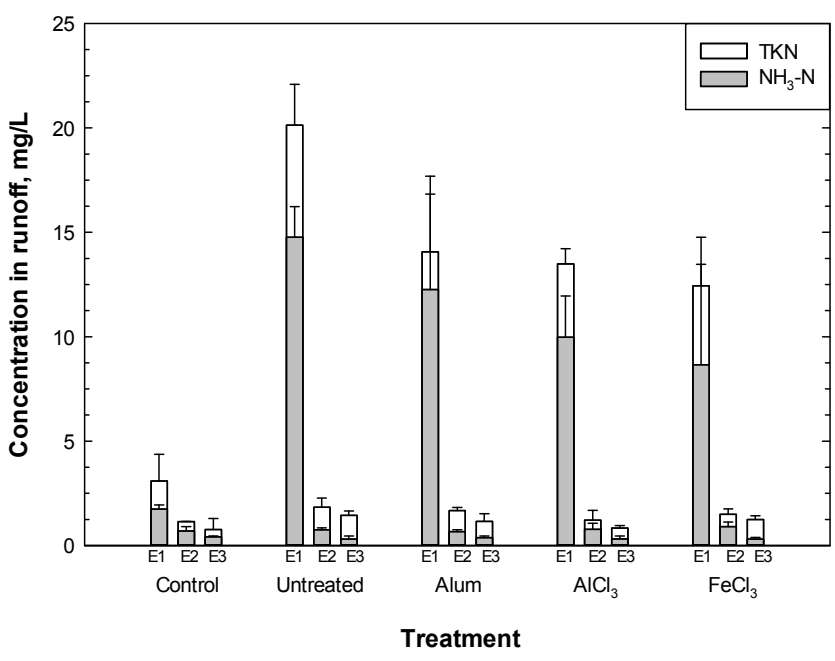

Figure 3. Flow-weighted mean (of three replications) runoff total Kjeldahl $\mathbf{N}(\mathrm{TKN})$ and ammonia $\mathrm{N}\left(\mathrm{NH}_{3}-\mathrm{N}\right)$ concentrations for the first (E1), second (E2), and third (E3) simulated rainfall events. Error bars indicate one standard deviation.

significantly greater than from the control plots. Addition of $\mathrm{AlCl}_{3}$ and $\mathrm{FeCl}_{3}$ significantly reduced $\mathrm{NH}_{3}-\mathrm{N}$ concentrations relative to unamended manure, but there were no significant differences among the alum, $\mathrm{AlCl}_{3}$, and $\mathrm{FeCl}_{3}$ amendments. While manure addition led to significantly higher first-event TKN concentrations than from the control plots (fig. 3), each of the chemical amendments significantly reduced TKN concentrations relative to unamended manure. Differences among the amendments' performance were not statistically significant. The reductions in first-event TKN concentrations due to $\mathrm{AlCl}_{3}$ and $\mathrm{FeCl}_{3}$ amendment follow from their effects on $\mathrm{NH}_{3}-\mathrm{N}$ concentrations; the effect of alum on runoff TKN concentrations appears to have occurred due to the relatively low organic $\mathrm{N}$ concentration in first-event runoff found for the plots receiving alum-amended manure (fig. 3).

As anticipated, addition of manure generally increased runoff FC concentrations relative to the control plots (fig. 4). Concentrations for the unamended manure, alum, and $\mathrm{AlCl}_{3}$

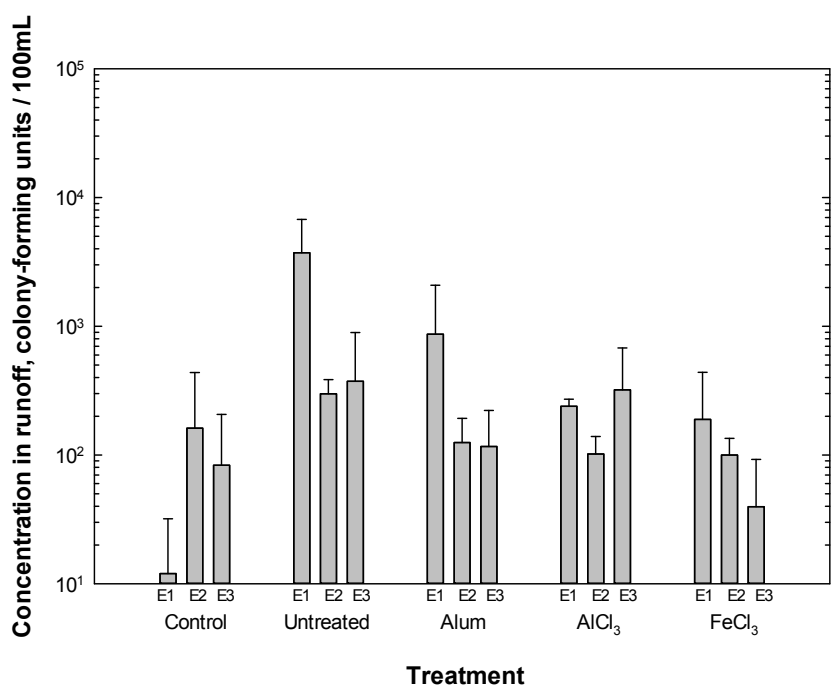

Figure 4. Flow-weighted mean (of three replications) runoff fecal coliform concentrations for the first (E1), second (E2), and third (E3) simulated rainfall events. Error bars indicate one standard deviation. 
amendments were each significantly greater than from the control plots and did not significantly differ from one another. However, FC concentrations for $\mathrm{FeCl}_{3}$ amendment were significantly less than from unamended manure and did not significantly differ from the control plots or those receiving alum-amended and $\mathrm{AlCl}_{3}$-amended manure. The conditions of this study did not permit a direct evaluation of the mechanisms responsible for the effect of $\mathrm{FeCl}_{3}$ on runoff $\mathrm{FC}$ concentrations, and a higher degree of experimental control (especially with regard to plot runoff characteristics) would likely be required to more fully investigate the issue.

\section{MASS LOSS RATES}

Mass loss rates (per-unit-area constituent masses lost in runoff; products of flow-weighted mean concentrations and plot runoff volumes divided by plot area, with appropriate unit conversions) are shown in figures 5 through 8 for all manure treatments and all simulated rainfall events. Except in the case of $\mathrm{NO}_{3}-\mathrm{N}$, no treatment effects persisted beyond the first simulated rainfall event. For each of the three simulated rainfall events, mass loss rates of DP for all the chemically amended (alum, $\mathrm{AlCl}_{3}$, and $\mathrm{FeCl}_{3}$ ) manure treatments were statistically indistinguishable from background levels and significantly less than from the plots receiving unamended manure (fig. 5). First-event mass loss rates of TP resulting from alum and $\mathrm{AlCl}_{3}$ amendment (which did not significantly differ from one another) were significantly less than for unamended manure, although significantly greater than for the control plots (fig. 5). However, first-event mass loss rates for $\mathrm{FeCl}_{3}$ amendment were significantly less than from the unamended, alum-amended, or $\mathrm{AlCl}_{3}$-amended manures and not significantly different from the control plots (fig. 5). Neither alum nor $\mathrm{AlCl}_{3}$ amendment reduced firstevent $\mathrm{NH}_{3}-\mathrm{N}$ mass loss rates relative to unamended manure; however, $\mathrm{FeCl}_{3}$ amendment was associated with mass loss rates that were significantly less than unamended, alumamended, and $\mathrm{AlCl}_{3}$-amended manure and not significantly different than from the control plots (fig. 6). With regard to $\mathrm{TKN}$, unamended and alum-amended manure led to mass

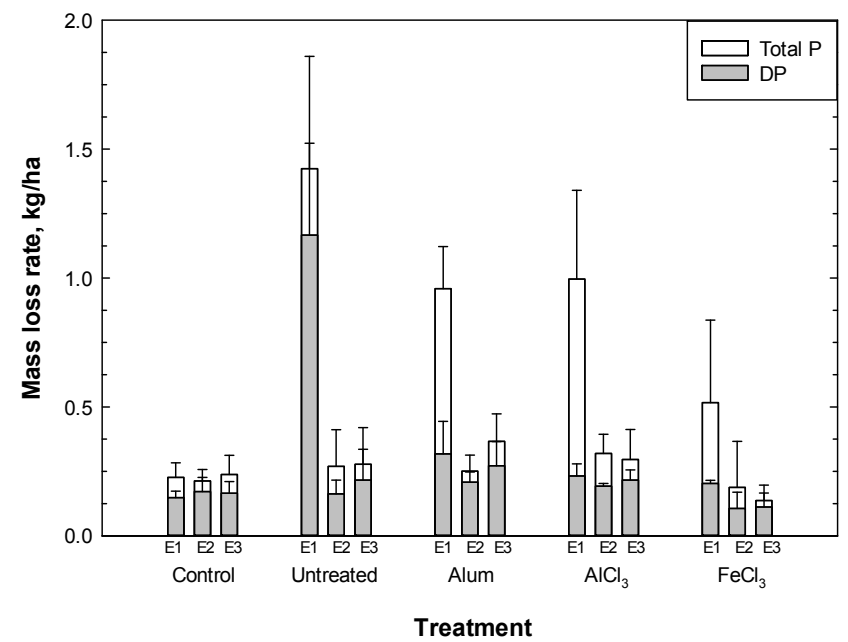

Figure 5. Mean (of three replications) runoff mass loss rates of total $P$ and dissolved reactive $P$ (DP) for the first (E1), second (E2), and third (E3) simulated rainfall events. Error bars indicate one standard deviation.

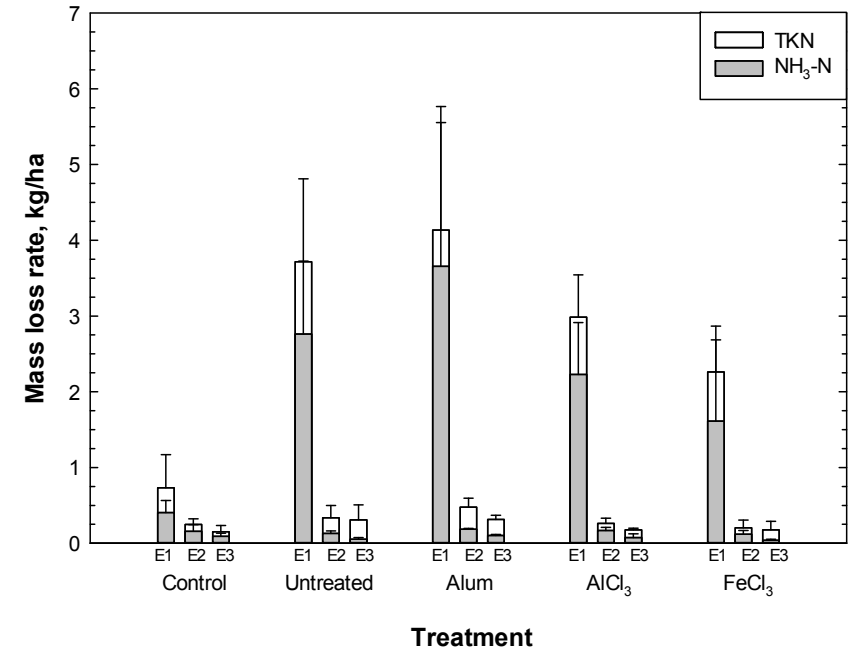

Figure 6. Mean (of three replications) runoff mass loss rates of total Kjeldahl $\mathbf{N}(\mathrm{TKN})$ and ammonia $\mathbf{N}\left(\mathrm{NH}_{3}-\mathrm{N}\right)$ for the first (E1), second (E2), and third (E3) simulated rainfall events. Error bars indicate one standard deviation.

loss rates that were significantly greater than from the control plots; no other differences among manure treatments were significant (fig. 6). Alum amendment led to $\mathrm{NO}_{3}-\mathrm{N}$ mass loss rates that were significantly greater than from $\mathrm{FeCl}_{3}$ amendment or unamended manure for the first simulated rainfall event and significantly greater than from $\mathrm{FeCl}_{3}$ amendment and the control plots for the second simulated rainfall event (fig. 7). No other significant differences among manure treatments or simulated rainfall events were found. Regardless of whether unamended or chemically amended, manure application led to TSS mass loss rates that were significantly greater than from the control plots (fig. 8). Alum amendment led to TSS mass loss rates that were significantly greater than for $\mathrm{FeCl}_{3}$ amendment, but no other significant manure treatment differences were present.

It should be borne in mind that the degree to which the mass loss rates results diverge from the concentration results is a reflection of the degree to which runoff was influenced by manure treatment and/or uncontrolled soil hydraulic char-

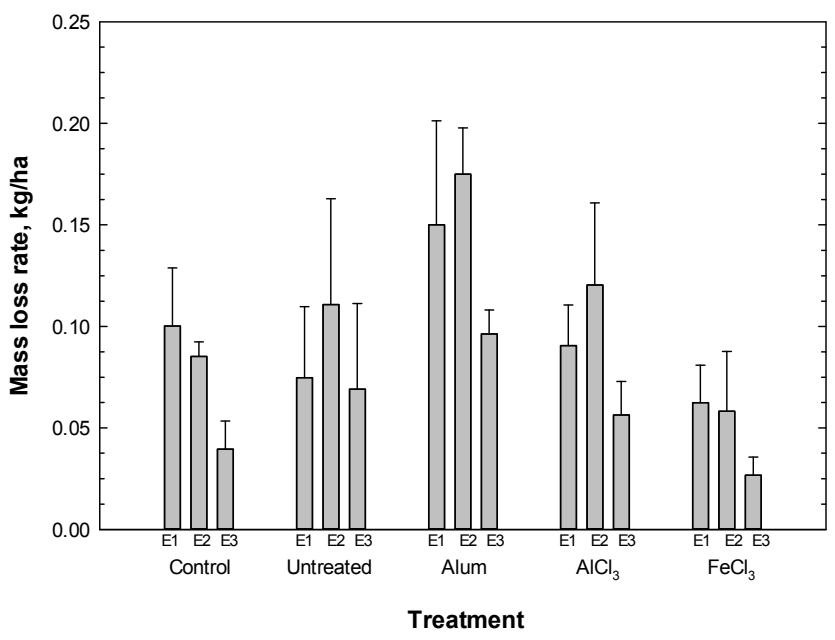

Figure 7. Mean (of three replications) runoff mass loss rates of nitrate $\mathrm{N}\left(\mathrm{NO}_{3}-\mathrm{N}\right)$ for the first (E1), second (E2), and third (E3) simulated rainfall events. Error bars indicate one standard deviation. 


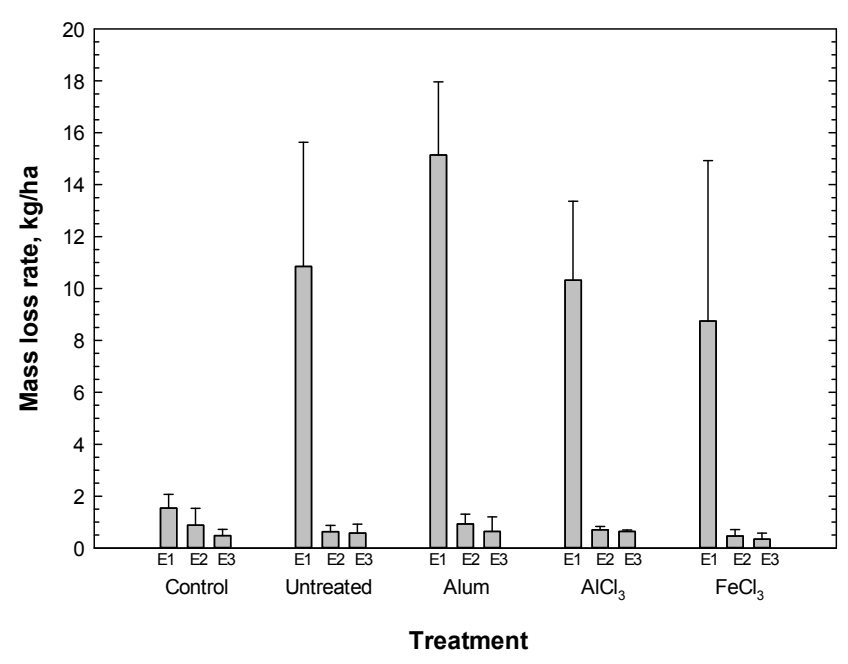

Figure 8. Mean (of three replications) runoff mass loss rates of total suspended solids for the first (E1), second (E2), and third (E3) simulated rainfall events. Error bars indicate one standard deviation.

acteristics. The findings reported in the preceding paragraph are therefore related not only to the amendments' interactions with the manure but also to the influence of the amendments and/or other factors on runoff. As a result of how mass loss rates are calculated, the influences are multiplicative.

It follows from figures 5 and 6 that the total mass loss rates of $\mathrm{N}$ and $\mathrm{P}$ over the three simulated rainfall events were small in comparison to the amounts applied (table 2). For example, total TP losses from the plots receiving alumamended manure were only $5.8 \%$ of applied, and the threeevent sum of TKN losses from the plots receiving unamended manure was only $3.4 \%$ of the amount applied. As has been reported in similar studies involving animal manure application (e.g., Edwards and Daniel, 1994a, 1994b), mass loss rates of these magnitudes are often agronomically insignificant, even under the very high simulated rainfall intensity used in this study.

\section{SUMMARY AND CONCLUSIONS}

Addition of chemical amendments (alum, $\mathrm{AlCl}_{3}$, and $\left.\mathrm{FeCl}_{3}\right)$ at stoichiometric rates of $1.1: 1$ to $1.3: 1$ [Al:TP] affected, although not consistently, both the hydrologic parameters and quality of runoff from fescue plots treated with swine manure. Plots that received swine manure amended with $\mathrm{FeCl}_{3}$ showed a lower runoff potential; these plots required more rainfall to produce runoff and yielded lower runoff. Each of the chemical amendments significantly reduced runoff DP concentrations relative to unamended manure, producing runoff DP concentrations that were not significantly different from background (no manure application) concentrations. All chemical amendments significantly reduced runoff TP concentrations relative to untreated manure, largely due to the amendments' effects on runoff DP concentrations rather than on other forms of $\mathrm{P}$ (e.g., particulate P). None of the chemical amendments significantly reduced runoff TSS concentrations relative to unamended manure. All chemical amendments significantly reduced runoff TKN concentrations relative to unamended manure, and both $\mathrm{AlCl}_{3}$ and $\mathrm{FeCl}_{3}$ amendment led to significant reductions in runoff $\mathrm{NH}_{3}-\mathrm{N}$ concentrations. Runoff $\mathrm{FC}$ concentrations were unaffected by the aluminum-based amendments, but $\mathrm{FeCl}_{3}$ amendment produced concentrations that were not significantly different from the plots receiving no manure. Mass loss rates generally, although not uniformly, mirrored the concentration results, with differences largely attributable to variation in the plots' soil hydraulic characteristics. Summed over the three simulated rainfall events, mass loss rates of $\mathrm{N}$ and $\mathrm{P}$ were small proportions of the amounts applied.

One of the major challenges to the practical application of this research includes assessing the economic implications of using the amendments for runoff quality improvements and identifying appropriate scenarios for their use (O'Flynn et al., 2013; Murnane et al., 2015). Moore et al. (1999) reported a benefit:cost ratio of 1.96 for alum addition to poultry litter based solely on poultry productivity considerations and increased litter N content. Similar work will be required to provide a parallel perspective on the implications of using the amendments of this study in association with swine production. Closely related is the challenge of optimizing amendment application rates and mixing techniques; given that amendments applied at comparable stoichiometric rates sometimes differed in terms of performance, other variables appear to be operative. Additional challenges to practical implementation of this work include identifying any amendment effects on swine production and/or manure storage facilities. Finally, future research ultimately needs to be validated for a full-scale swine production facility, and any long-term effects of adding treated manure to the soil should be investigated to avoid adverse impacts.

\section{ACKNOWLEDGEMENTS}

This is Publication No. 16-05-047 of the Kentucky Agricultural Experiment Station and is published with the approval of the Director. This work is supported by the USDA National Institute of Food and Agriculture (NIFA) HatchMultistate Project under 1006093. We are sincerely grateful to the anonymous reviewers, editors, and editorial staff for their assistance in improving the quality of the manuscript.

\section{REFERENCES}

APHA. (2012). Standard methods for the examination of water and wastewater. 22nd Ed. Washington, DC: American Water Works Association.

Barton, C., \& Karathanasis, T. (2002). A novel method for measurement and characterization of soil macroporosity. Comm. Soil Sci. Plant Anal., 33(7-8), 1305-1322. http://dx.doi.org/10.1081/CSS-120003889

Bonnin, G. M., Martin, D., Lin, B., Parzybok, T., Yekta, M., \& Riley, D. (2006). NOAA Atlas 14: Precipitation-frequency atlas of the United States, Vol. 2, Ver. 3.0: Delaware, District of Columbia, Illinois, Kentucky, Maryland, New Jersey, North Carolina, Ohio, Pennsylvania, South Carolina, Tennessee, Virginia, West Virginia. Silver Spring, MD: National Weather Service. Retrieved from

http://www.nws.noaa.gov/oh/hdsc/PF_documents/Atlas14_Volu me2.pdf

Brennan, R. B., Healy, M. G., Grant, J., Ibrahim, T. G., \& Fenton, 
O. (2012). Incidental phosphorus and nitrogen loss from grassland plots receiving chemically amended dairy cattle slurry. Sci. Total Environ., 441, 132-140.

http://dx.doi.org/10.1016/j.scitotenv.2012.09.078

Burnison, B. K., Hartmann, A., Lister, A., Servos, M. R., Ternes, T., \& Van Der Kraak, G. (2003). A toxicity identification evaluation approach to studying estrogenic substances in hog manure and agricultural runoff. Environ. Toxicol. Chem., 22(10), 2243-2250. http://dx.doi.org/10.1897/02-437

Burns, J. C., Westerman, P. W., King, L. D., Cummings, G. A., Overcash, M. R., \& Goode, L. (1985). Swine lagoon effluent applied to 'coastal' bermudagrass: I. Forage yield, quality, and element removal. J. Environ. Qual., 14(1), 9-14. http://dx.doi.org/10.2134/jeq1985.00472425001400010002x

Burns, J. C., Westerman, P. W., King, L. D., Overcash, M. R., \& Cummings, G. A. (1987). Swine manure and lagoon effluent applied to a temperate forage mixture: I. Persistence, yield, quality, and elemental removal. J. Environ. Qual., 16(2), 99-105. http://dx.doi.org/10.2134/jeq1987.00472425001600020002x

Burton, C. H. (2007). The potential contribution of separation technologies to the management of livestock manure. Livestock Sci., 112(3), 208-216. http://dx.doi.org/10.1016/j.livsci.2007.09.004

Busheé, E. L., Edwards, D. R., \& Moore Jr., P. A. (1998). Quality of runoff from plots treated with municipal sludge and horse bedding. Trans. ASAE, 41(4), 1035-1041. http://dx.doi.org/10.13031/2013.17266

Chaubey, I., Edwards, D. R., Daniel, T. C., Moore Jr., P. A., \& Nichols, D. J. (1994). Effectiveness of vegetative filter strips in retaining surface-applied swine manure constituents. Trans. ASAE, 37(3), 845-850. http://dx.doi.org/10.13031/2013.28149

Choudhary, M., Bailey, L. D., \& Grant, C. A. (1996). Review of the use of swine manure in crop production: Effects on yield and composition and on soil and water quality. Waste Mgmt. Res., 14(6), 581-595. http://dx.doi.org/10.1177/0734242x9601400606

Diricx, M., Sinha, A. K., Liew, H. J., Mauro, N., Blust, R., \& De Boeck, G. (2013). Compensatory responses in common carp (Cyprinus carpio) under ammonia exposure: Additional effects of feeding and exercise. Aquat. Toxicol., 142-143, 123-137. http://dx.doi.org/10.1016/j.aquatox.2013.08.007

Edwards, D. R., \& Daniel, T. C. (1993). Runoff quality impacts of swine manure applied to fescue plots. Trans. ASAE, 36(1), 8186. http://dx.doi.org/10.13031/2013.28317

Edwards, D. R., \& Daniel, T. C. (1994a). Quality of runoff from fescuegrass plots treated with poultry litter and inorganic fertilizer. J. Environ. Qual., 23(3), 579-584. http://dx.doi.org/10.2134/jeq1994.00472425002300030025x

Edwards, D. R., \& Daniel, T. C. (1994b). A comparison of runoff quality effects of organic and inorganic fertilizers applied to fescuegrass plots. JAWRA, 30(1), 35-41. http://dx.doi.org/10.1111/j.1752-1688.1994.tb03271.x

Humphry, J. B., Daniel, T. C., Edwards, D. R., \& Sharpley, A. N. (2002). A portable rainfall simulator for plot-scale runoff studies. Appl. Eng. Agric., 18(2), 199-204. http://dx.doi.org/10.13031/2013.7789

King, L. D., Westerman, P. W., Cummings, G. A., Overcash, M. R., \& Burns, J. C. (1985). Swine lagoon effluent applied to 'coastal' bermudagrass: II. Effects on soil. J. Environ. Qual., 14(1), 14-21. http://dx.doi.org/10.2134/10.2134/jeq1985.004724250014000100 $03 \mathrm{x}$

Lee, H. B., \& Liu, D. (2002). Degradation of $17 \beta$-estradiol and its metabolites by sewage bacteria. Water Air Soil Pollut., 134(1), 351-366. http://dx.doi.org/10.1023/a:1014117329403

Malecki-Brown, L. M., White, J. R., \& Sees, M. (2009). Alum application to improve water quality in a municipal wastewater treatment wetland. J. Environ. Qual., 38(2), 814-821. http://dx.doi.org/10.2134/jeq2008.0033

Mc Leod, R. V., \& Hegg, R. O. (1984). Pasture runoff water quality from application of inorganic and organic nitrogen sources. $J$. Environ. Qual., 13(1), 122-126. http://dx.doi.org/10.2134/jeq1984.00472425001300010022x

Mehlich, A. (1984). Mehlich-3 soil test extractant: A modification of Mehlich-2 extractant. Comm. Soil Sci. Plant Anal., 15(12), 1409-1416. http://dx.doi.org/10.1080/00103628409367568

Moore Jr., P. A., \& Miller, D. M. (1994). Decreasing phosphorus solubility in poultry litter with aluminum, calcium, and iron amendments. J. Environ. Qual., 23(2), 325-330. http://dx.doi.org/10.2134/jeq1994.00472425002300020016x

Moore Jr., P. A., Daniel, T. C., \& Edwards, D. R. (1999). Reducing phosphorus runoff and improving poultry production with alum. Poultry Sci., 78(5), 692-698.

http://dx.doi.org/10.1093/ps/78.5.692

Moore Jr., P. A., Daniel, T. C., Gilmour, J. T., Shreve, B. R., Edwards, D. R., \& Wood, B. H. (1998). Decreasing metal runoff from poultry litter with aluminum sulfate. J. Environ. Qual., 27(1), 92-99. http://dx.doi.org/10.2134/jeq1998.00472425002700010014x

Moss, C. G., Edwards, D. R., Workman, S. R., \& Williams, R. M. (1999). Runoff from fescue plots treated with trimec. Trans. ASAE, 42(6), 1631-1636. http://dx.doi.org/10.13031/2013.13329

Murnane, J. G., Brennan, R. B., Healy, M. G., \& Fenton, O. (2015). Use of zeolite with alum and polyaluminum chloride amendments to mitigate runoff losses of phosphorus, nitrogen, and suspended solids from agricultural wastes applied to grassed soils. J. Environ. Qual., 44(5), 1674-1683. http://dx.doi.org/10.2134/jeq2014.07.0319

National Pork Board. (2014). Pork stats 2014. Des Moines, IA: National Pork Board. Retrieved from https://www.pork.org/pork-quick-facts/home/

Nichols, D. J., Daniel, T. C., Moore Jr., P. A., Edwards, D. R., \& Pote, D. H. (1997). Runoff of estrogen hormone $17 \beta$-estradiol from poultry litter applied to pasture. J. Environ. Qual., 26(4), 1002-1006. http://dx.doi.org/10.2134/jeq1997.00472425002600040011x

NRCS. (2012). Nutrient management. Conservation Practice Standard 590. Washington, DC: USDA Natural Resources Conservation Service.

O’Flynn, C. J., Fenton, O., Wilson, P., \& Healy, M. G. (2012). Impact of pig slurry amendments on phosphorus, suspended sediment, and metal losses in laboratory runoff boxes under simulated rainfall. J. Environ. Mgmt., 113, 78-84. http://dx.doi.org/10.1016/j.jenvman.2012.08.026

O’Flynn, C. J., Healy, M. G., Wilson, P., Hoekstra, N. J., Troy, S. M., \& Fenton, O. (2013). Chemical amendment of pig slurry: Control of runoff related risks due to episodic rainfall events up to $48 \mathrm{~h}$ after application. Environ. Sci. Pollut. Res., 20(9), 60196027. http://dx.doi.org/10.1007/s11356-013-1630-0

Patton, M., \& Seidl, A. (1999). Matrix of state level policies for animal feeding operations. Agricultural and Resource Policy Report APR 99-01. Fort Collins, CO: Colorado State University, Department of Agricultural and Resource Economics.

Retrieved from http://hermes.cde.state.co.us/drupal/islandora/object/co\%3A4175

Perfect, E., \& Blevins, R. L. (1997). Fractal characterization of soil aggregation and fragmentation as influenced by tillage treatment. SSSA J., 61(3), 896-900. http://dx.doi.org/10.2136/sssaj1997.03615995006100030026x

Schiffer, B., Daxenberger, A., Meyer, K., \& Meyer, H. H. (2001). The fate of trenbolone acetate and melengestrol acetate after application as growth promoters in cattle: Environmental studies. Environ. Health Perspect., 109(11), 1145-1151. http://dx.doi.org/10.2307/3454862 
Schindler, D. W. (1977). Evolution of phosphorus limitation in lakes. Science, 195(4275), 260-262.

http://dx.doi.org/10.1126/science.195.4275.260

Sharpe, R. M., \& Skakkebaek, N. E. (1993). Are oestrogens involved in falling sperm counts and disorders of the male reproductive tract? The Lancet, 341(8857), 1392-1396. http://dx.doi.org/10.1016/0140-6736(93)90953-E

Sharpley, A. N., Smith, S. J., Jones, O. R., Berg, W. A., \& Coleman, G. A. (1992). The transport of bioavailable phosphorus in agricultural runoff. J. Environ. Qual., 21(1), 3035. http://dx.doi.org/10.2134/jeq1992.00472425002100010003x

Shore, L. S., Gurevitz, M., \& Shemesh, M. (1993). Estrogen as an environmental pollutant. Bull. Environ. Contam. Toxicol., 51(3), 361-366. http://dx.doi.org/10.1007/bf00201753

Shreve, B. R., Moore Jr., P. A., Daniel, T. C., Edwards, D. R., \& Miller, D. M. (1995). Reduction of phosphorus in runoff from field-applied poultry litter using chemical amendments. $J$. Environ. Qual., 24(1), 106-111. http://dx.doi.org/10.2134/jeq1995.00472425002400010015x
Sonzogni, W. C., Chapra, S. C., Armstrong, D. E., \& Logan, T. J. (1982). Bioavailability of phosphorus inputs to lakes. J. Environ. Qual., 11(4), 555-563.

http://dx.doi.org/10.2134/jeq1982.00472425001100040001x

Tijani, J. O., Fatoba, O. O., \& Petrik, L. F. (2013). A review of pharmaceuticals and endocrine-disrupting compounds: Sources, effects, removal, and detections. Water Air Soil Pollut., 224(11), 1-29. http://dx.doi.org/10.1007/s11270-013-1770-3

Vadas, P. A., Harmel, R. D., \& Kleinman, P. J. A. (2007). Transformations of soil and manure phosphorus after surface application of manure to field plots. Nutr. Cycling Agroecosyst., 77(1), 83-99. http://dx.doi.org/10.1007/s10705-006-9047-5

Westerman, P. W., King, L. D., Burns, J. C., Cummings, G. A., \& Overcash, M. R. (1987). Swine manure and lagoon effluent applied to a temperate forage mixture: II. Rainfall runoff and soil chemical properties. J. Environ. Qual., 16(2), 106-112. http://dx.doi.org/10.2134/jeq1987.00472425001600020003x

Williams, R., \& Edwards, D. D. (2016). Effects of biochar treatment of municipal biosolids and horse manure on quality of runoff from fescue plots. Trans. ASABE, (in review). 